\title{
MINOR CONSTITUENTS FROM RUBIA CORDIFOLIA L. ROOT
}

\author{
Zedan Z. Ibraheim and Yaser G. Gouda
}

Department of Pharmacognosy, Faculty of Pharmacy, Assiut University, Assiut, 71526, Egypt

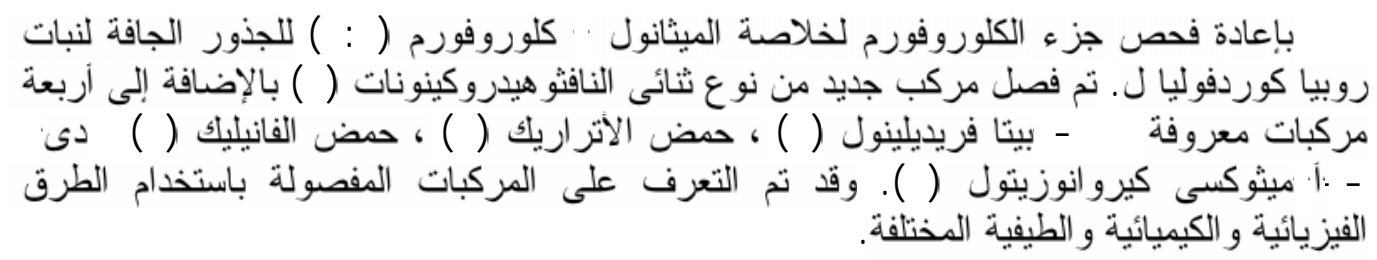

Reinvestigation of the chloroform soluble fraction of the chloroform- methanol (1:1) extract of the dried roots of Rubia cordifolia L. using different chromatographic techniques led to isolation of one new naphthohydroquinone dimer (1) and four known compounds identified as 3- $\beta$-friedelinol (2), atraric acid (3), vanillic acid (4) and D-3-O-methoxy-chiro-inositol (5). The identification of the isolated compounds was carried out using different physical, chemical and spectral methods of analysis.

\section{INTRODUCTION}

Rubia cordifolia L. (Rubiaceae), is an important medicinal plant used for treatment of various diseases such as tumors ${ }^{1-10}$, inflammations, urinary disorders, stress and as antimicrobial $^{10-21}$, hepatoprotective ${ }^{7,22 \& 23}$, radioprotective $^{24}$, hypoglycemic $c^{7,25 \& 26}$ and antipsychotic $^{27}$. It has been listed officially as a herbal medicine in Chinese Pharmacopeia for treatment of arthritis, dysmenorrhea, hematorrhea and hemostasis which are free radical related diseases ${ }^{7,23,24 \& 28-30}$. It is used also as natural food colourant and as natural hair and colour dye ${ }^{7}$.

Many classes of compounds were isolated from the roots of $R$. cordifolia L. ${ }^{2,7,23 \& 31-45}$, besides large numbers of cyclic hexapeptides $^{1-4 \& 23}$. In the current study, a new naphthohydroquinone dimer (1) and four known compounds (2-5) were isolated and identified.

\section{MATERIALS AND METHODS}

\section{Experimental}

Melting points (uncorrected) were determined by electrothermal digital model 550. IR spectrum was recorded in $\mathrm{KBr}$ using Unicam SP 1025 spectrophotometer. ${ }^{1} \mathrm{H}$ - and ${ }^{13} \mathrm{C}$-NMR spectra were recorded in $\mathrm{CDCl}_{3}$ (or
$\mathrm{C}_{5} \mathrm{D}_{5} \mathrm{~N}$ or $\mathrm{CD}_{3} \mathrm{OD}$ ) at $400 \mathrm{MHz}$ and $100 \mathrm{MHz}$ respectively, with TMS as an internal standard on Bruker AM-400 spectrometer. Mass spectra were carried out using Hitachi M-80 spectrometer. For CC, silica gel (E. Merck, Germany 70-230 mesh) and reversed phase (RP-18, ODS) were used. Precoated silica gel

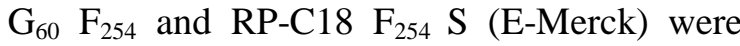
used for TLC and $10 \% \mathrm{H}_{2} \mathrm{SO}_{4}$ was used as spraying reagent followed by heating for 10 minutes. Final purification was carried out using Moderate Pressure Liquid Chromatography (MPLC) $(22 \mathrm{~mm}$, i.d. x $30 \mathrm{~cm}$, Kusano Scientific co., Tokyo, Japan).

\section{Plant material}

The dried roots of Rubia cordifolia L. were purchased from India and identified by Dr. Sang Rae Lee (Institute of Oriental Botanical Resources of Korea). A voucher sample (No. 20103) was kept in the Herbarium of Pharmacognosy Department, Faculty of Pharmacy, Assiut University, Assiut, Egypt as a reference material. The powdered roots were extracted and kept in refrigerator till used.

\section{Extraction and isolation}

The air-dried powdered root of Rubia cordifolia L. $(20 \mathrm{Kg})$ was extracted with chloroform-methanol (1:1) till exhaustion $(3 \times 30 \quad$ L). The combined extract was 
evaporated till dryness. The dried extract was suspended in distilled water and extracted with chloroform to give $1890 \mathrm{~g}$ of chloroformic extract.

Part of the dried chloroform fraction (60 g) was chromatographed over silica gel column $(2 \mathrm{~kg})$, eluted with hexane-EtOAc gradiently and finally the column was washed with EtOAc-MeOH (9:1). Fractions (300 ml, each) were collected and monitored using TLC and $10 \% \mathrm{H}_{2} \mathrm{SO}_{4}$ as spraying reagent; similar fractions were pooled.

Fractions eluted with hexane-EtOAc (8:2) were subjected to silica gel $\mathrm{CC}$ using hexaneEtOAc (85:15), where sub-fractions 5-9 (containing similar spots) were rechromatographed over silica gel $\mathrm{CC}$ using $\mathrm{CH}_{2} \mathrm{Cl}_{2}-$ acetone (95:5), then final purification was done using (MPLC) RP-18 CC and methanol-water (7:3) to afford compound $\mathbf{1}(7 \mathrm{mg})$ and compound 2 (8 mg).

Fractions eluted with hexane-EtOAc (7:3) were subjected to silica gel $\mathrm{CC}$ using hexaneEtOAc (75:25) followed by RP-18 CC (MPLC) using methanol-water (7:3). Upon repeated crystallization, sub-fractions 3-8 afforded compound 3 (6 mg, methanol) while subfractions 10-12 afforded compound 4 (12 mg, methanol).

Fractions eluted with EtOAc-MeOH (9:1) were rechromatographed over silica gel $\mathrm{CC}$ using $\mathrm{CHCl}_{3}-\mathrm{MeOH}$ in a gradient elution technique. Fractions eluted with $\mathrm{CHCl}_{3}-\mathrm{MeOH}$ (9:1) were chromatographed over silica gel CC, followed by RP-18 CC (MPLC) using $\mathrm{CH}_{3} \mathrm{CN}$ $\mathrm{H}_{2} \mathrm{O}$ (25:75), where sub-fractions (16-20) were purified by re-crystallization from methanol to afford compound $\mathbf{5}$ (11 mg).

Compound 1: yellowish-brown amorphous powder. IR (KBr): 3420, 1670, 1642, 1602 $\mathrm{cm}^{-1}$. ${ }^{1} \mathrm{H}-\mathrm{NMR}\left(400 \mathrm{MHz}, \mathrm{CDCl}_{3}\right.$ ) and ${ }^{13} \mathrm{C}-$ NMR (100 MHz, $\mathrm{CDCl}_{3}$ ) (Table 1).

Compound 2: white fine needles. m.p. 281-283 ${ }^{\circ}$ C. EI-MS $\mathrm{m} / z$ (\% rel. int.): $428[\mathrm{M}]^{+}$ (20) 413 (29), 275 (36), 248 (19), 231 (30), 220 (34), 205 (24), 177 (20), 165 (52), 125 (83), 95 (100, base peak), 69 (58) and 55 (56). ${ }^{1} \mathrm{H}-\mathrm{NMR}$ $\left(400 \mathrm{MHz}, \mathrm{CDCl}_{3}\right): \delta_{\mathrm{H}} 0.84\left(3 \mathrm{H}, \mathrm{s}, \mathrm{CH}_{3}-25\right)$, $0.91\left(3 \mathrm{H}, \mathrm{s}, \mathrm{CH}_{3}-29\right), 0.92\left(3 \mathrm{H}, \mathrm{s}, \mathrm{CH}_{3}-26\right)$, $0.93\left(3 \mathrm{H}, \mathrm{d}, J=8 \mathrm{~Hz}, \mathrm{CH}_{3}-23\right), 0.97(6 \mathrm{H}, \mathrm{s}$, $\mathrm{CH}_{3}-27$ \& 30), 0.98 (3H, s, $\left.\mathrm{CH}_{3}-24\right), 1.15(3 \mathrm{H}$, s, $\left.\mathrm{CH}_{3}-28\right), 3.72$ (1H, br.s, H-3). ${ }^{13} \mathrm{C}-\mathrm{NMR}(100$ $\left.\mathrm{MHz}, \mathrm{CDCl}_{3}\right): \delta_{\mathrm{C}} 16.10(\mathrm{C}-1, \mathrm{t}), 36.30(\mathrm{C}-2, \mathrm{t})$,
72.97 (C-3, d), 49.38 (C-4, d), 38.05 (C-5, s), $41.94(\mathrm{C}-6, \mathrm{t}), 17.77$ (C-7, t), $53.41(\mathrm{C}-8, \mathrm{~d})$, $37.32(\mathrm{C}-9, \mathrm{~s}), 61.56(\mathrm{C}-10, \mathrm{~d}), 35.56(\mathrm{C}-11, \mathrm{t})$, $30.86(\mathrm{C}-12, \mathrm{t}), 38.59(\mathrm{C}-13, \mathrm{~s}), 39.89$ (C-14, s), $32.55(\mathrm{C}-15, \mathrm{t}), 35.77(\mathrm{C}-16, \mathrm{t}), 30.24(\mathrm{C}-17$, s), 43.03 (C-18, d), 35.40 (C-19, t), 28.40 (C20, s), 33.03 (C-21, t), 39.50 (C-22, t), 11.85 (C-23, q), 16.62 (C-24, q), 18.47 (C-25, q), 20.34 (C-26, q), 18.88 (C-27, q), 32.01 (C-28, q), 35.25 (C-29, q), 32.31 (C-30, q).

Compound 3: pale yellow amorphous powder. EI-MS: $\mathrm{m} / \mathrm{z}$ (\% rel. int.): $196[\mathrm{M}]^{+}$ (45), 164 (100, base peak) and $136(60) .{ }^{1} \mathrm{H}-$ NMR $\left(400 \mathrm{MHz}, \mathrm{CDCl}_{3}\right): \delta_{\mathrm{H}} 12.00(1 \mathrm{H}, \mathrm{s}$, $\mathrm{OH}), 6.19(1 \mathrm{H}, \mathrm{s}, \mathrm{H}-5), 3.90\left(3 \mathrm{H}, \mathrm{s}, \mathrm{OCH}_{3}\right)$, 2.43 (3H, s, C-6 methyl), $2.08(3 \mathrm{H}, \mathrm{s}, \mathrm{C}-3$ methyl). ${ }^{13} \mathrm{C}-\mathrm{NMR}\left(100 \mathrm{MHz}, \mathrm{CDCl}_{3}\right): \delta_{\mathrm{C}} \mathrm{C}-1-$ C-6: 105.37 (s), 163.36 (s), 108.75 (s), 158.37 (s), 110.77 (d), 140.32 (s); Me-C-3: 7.88 (q); Me-C-6: 24.31 (q); COOMe: 169.76 (s), 52.01 (q).

Compound 4: faint brown needles, m.p. 211-213 ${ }^{\circ} \mathrm{C}$. CI-MS $\mathrm{m} / \mathrm{z}$ (\% rel. int.): 169 $[\mathrm{M}+1]^{+}(100), 148(30), 125$ (26), 79 (23), 69 (41) and 51 (20). ${ }^{1} \mathrm{H}-\mathrm{NMR}\left(400 \mathrm{MHz}, \mathrm{C}_{5} \mathrm{D}_{5} \mathrm{~N}\right)$ : $\delta 8.13(1 \mathrm{H}, \mathrm{dd}, J=1.9,8.2 \mathrm{~Hz}, \mathrm{H}-6), 8.04(1 \mathrm{H}$, d, $J=1.9 \mathrm{~Hz}, \mathrm{H}-2), 7.31(1 \mathrm{H}, \mathrm{d}, J=8.2 \mathrm{~Hz}, \mathrm{H}-$ 5), $3.94\left(3 \mathrm{H}, \mathrm{s}, \mathrm{OCH}_{3}\right)$.

Compound 5: white crystals, m.p. 180$182^{\circ} \mathrm{C}$. EI-MS $\mathrm{m} / z$ (\% rel. int.): $194[\mathrm{M}]^{+}(26)$, 163 (11) and 54 (100, base peak). ${ }^{1} \mathrm{H}-\mathrm{NMR}$ $\left(400 \mathrm{MHz}, \mathrm{CD}_{3} \mathrm{OD}\right): \delta 3.27(1 \mathrm{H}, \mathrm{t}, J=9.2 \mathrm{~Hz}$, $\mathrm{H}-3), 3.58(1 \mathrm{H}, \mathrm{t}, J=9.2 \mathrm{~Hz}), 3.69(1 \mathrm{H}, \mathrm{dd}, J=$ $2.4,10.0 \mathrm{~Hz}), 3.73(1 \mathrm{H}, \mathrm{dd}, J=2.4,10.0 \mathrm{~Hz})$, $3.88(2 \mathrm{H}, \mathrm{m}) .{ }^{13} \mathrm{C}-\mathrm{NMR}\left(100 \mathrm{MHz}, \mathrm{CD}_{3} \mathrm{OD}\right)$ : $\delta_{\mathrm{C}}$ C-1-C-6: 72.34 (d), 70.62 (d), 83.51 (d), 72.91 (d), 71.13 (d), 72.06 (d); OMe: 59.39 (q).

\section{RESULTS AND DISCUSSION}

From the chloroform soluble fraction of the chloroform-methanol extract of Rubia cordifolia, five compounds were isolated (1-5).

Compound 1: The IR spectrum of compound 1 showed the presence aromatic $\mathrm{CH}$ stretching, hydroxyl and ester groups (experimental part). The molecular formula was established as $\mathrm{C}_{34} \mathrm{H}_{30} \mathrm{O}_{9}$ from ${ }^{1} \mathrm{H}$ - and ${ }^{13} \mathrm{C}$ - including DEPT ${ }^{13} \mathrm{C}$-NMR spectral data (Table 1). The ${ }^{1} \mathrm{H}$-NMR spectrum showed the presence of ten protons in the aromatic region including a pair of $\mathrm{AA}^{`} \mathrm{BB} \mathrm{B}^{`}$ type aromatic system in the region at 
Table 1: ${ }^{13} \mathrm{C}-(100 \mathrm{MHz})$ and ${ }^{1} \mathrm{H}-\mathrm{NMR}(400 \mathrm{MHz})$ data of compound 1 (in $\left.\mathrm{CDCl}_{3}\right)$.

\begin{tabular}{|c|c|c|c|c|c|}
\hline $\mathrm{C}$ & $\delta_{\mathrm{C}}(\mathrm{m})$ & $\delta_{\mathrm{H}}(\mathrm{m})$ & $\mathrm{C}$ & $\delta_{\mathrm{C}}(\mathrm{m})$ & $\delta_{\mathrm{H}}(\mathrm{m})$ \\
\hline 1 & $158.61(\mathrm{~s})$ & - & 1 & $158.78(\mathrm{~s})$ & - \\
\hline 2 & $98.47(\mathrm{~s})$ & - & 2 & $98.34(\mathrm{~s})$ & - \\
\hline 3 & $120.93(\mathrm{~s})$ & - & 3 & $120.80(s)$ & - \\
\hline 4 & $142.86(\mathrm{~s})$ & - & 4 & $142.58(\mathrm{~s})$ & - \\
\hline 5 & $119.20(d)$ & $7.76(1 \mathrm{H}$, br. d, $8.1 \mathrm{~Hz})$ & 5 & $119.14(d)$ & $7.84(1 \mathrm{H}$, br. d, $8.0 \mathrm{~Hz})$ \\
\hline 6 & $129.53(\mathrm{~d})]$ & \multirow{2}{*}{ 7. $35-7.43(2 \mathrm{H}, \mathrm{m})$} & 6 & $129.50(d)$ & \multirow{2}{*}{ 7. 35-7. $43(2 \mathrm{H}, \mathrm{m})$} \\
\hline 7 & 125.06 (d) & & 7 & $125.06(\mathrm{~d}) \int$ & \\
\hline 8 & $124.53(d)$ & $8.27(1 \mathrm{H}$, br. d., $8.1 \mathrm{~Hz})$ & 8 & $124.30(\mathrm{~d})$ & $8.30(1 \mathrm{H}$, br. d, $8.0 \mathrm{~Hz})$ \\
\hline 9 & $122.07(\mathrm{~s})$ & - & 9 & $122.28(\mathrm{~s})$ & - \\
\hline 10 & $125.06(\mathrm{~s})$ & - & $10^{\prime}$ & $125.06(\mathrm{~s})$ & - \\
\hline 11 & $104.12(d)$ & $6.16(1 \mathrm{H}, \mathrm{s})$ & $11^{\prime}$ & $104.05(d)$ & $6.35(1 \mathrm{H}, \mathrm{s})$ \\
\hline 12 & $163.38(\mathrm{~s})$ & - & 12 & $160.89(\mathrm{~s})$ & - \\
\hline 13 & $72.87(\mathrm{~s})$ & - & $13^{`}$ & $35.74(\mathrm{~s})$ & - \\
\hline 14 & $27.67(q)$ & $1.46(3 \mathrm{H}, \mathrm{s})$ & 14 & $31.16(q)$ & $1.64(3 \mathrm{H}, \mathrm{s})$ \\
\hline 15 & $54.66(t)$ & $\begin{array}{l}2.79 \mathrm{~d}(1 \mathrm{H}, \mathrm{d}, 14.5 \mathrm{~Hz}) \\
2.44 \mathrm{~d}(1 \mathrm{H}, \mathrm{d}, 14.5 \mathrm{~Hz})\end{array}$ & 15 & $30.54(q)$ & $1.68(3 \mathrm{H}, \mathrm{s})$ \\
\hline 16 & $171.43(\mathrm{~s})$ & - & 16 & $171.43(\mathrm{~s})$ & - \\
\hline 17 & $51.82(q)$ & $3.56(3 \mathrm{H}, \mathrm{s})$ & 17 & $51.72(q)$ & $3.59(3 \mathrm{H}, \mathrm{s})$ \\
\hline$-\mathrm{OH}$ & & $11.93(1 \mathrm{H}$, br. $\mathrm{s})$ & & & $11.87(1 \mathrm{H}$, br. s) \\
\hline
\end{tabular}

$\mathrm{m}=$ multiplicity

$\delta_{\mathrm{H}}$ 7.53-8.30 (Table 1) and two singlet signals at $\delta_{\mathrm{H}} 6.35$ and 6.16 , in addition to two singlet protons in the most shielded region at $\delta_{\mathrm{H}} 11.93$ and 11.87 for two chelated hydroxyl aromatic groups. Seventeen protons in the aliphatic region were observed as three singlet methyl signals at $\delta_{\mathrm{H}} 1.46,1.64,1.68$; two methoxy singlet signals at $\delta_{\mathrm{H}} 3.56,3.59$ and two doublets (each equivalent to one proton) at $\delta_{\mathrm{H}}$ 2.79 and 2.44. The identification of each proton was confirmed by proton decoupling experiment. The ${ }^{13} \mathrm{C}-\mathrm{NMR}$ spectral data including DEPT mode measurement, revealed the presence of 30 carbon signals for 34 carbon atoms which include 10 methine, 1 methylene, 3 methyl, 2 methoxy and 18 quaternary atoms. The spectral data (Table 1) indicated that the two methoxy groups were observed at $\delta_{\mathrm{c}} 51.72$ and 51.82; the doublet signals at $\delta_{\mathrm{H}} 2.79$ and 2.44 in the ${ }^{1} \mathrm{H}-\mathrm{NMR}$ (each, $1 \mathrm{H}, \mathrm{d}, J=14.5 \mathrm{~Hz}$ ) with $\delta_{\mathrm{C}} 54.66$ indicated the presence of geminally coupled methylene proton. The aromatic protons with their ${ }^{13} \mathrm{C}-\mathrm{NMR}$ data in addition to the quaternary carbon atoms at $\delta_{\mathrm{C}}$ 171.43 and the two methoxy groups demonstrate the presence of two naphthohydroquinone moieties most probably $\mathrm{C}-12$ substituted furomollugin ${ }^{32}$. The chemical shifts of 28 carbon atoms in the ${ }^{13} \mathrm{C}-\mathrm{NMR}$ spectrum confirmed the presence of the two furomollugin moiety which are similar to that reported in the literature ${ }^{32 \& 33}$ while the remaining six carbons including two quaternary at $\delta_{\mathrm{C}} 72.87$ and 35.74 ; three methyls at $\delta_{\mathrm{C}}$ $27.67,30.54$ and 31.16 and one methylene at $\delta_{C}$ 54.66 were interpreted as shown in figure 1 . 
The location of the methylene group must be between the two aliphatic quaternary carbons since its presence between any of the two furomollugin groups and any of aliphatic quaternary carbons will make it resonate in the upfield region in the ${ }^{13} \mathrm{C}$-NMR spectra ${ }^{46}$. Many naphthohydroquinones and naphthoquinone dimers were isolated from the genus Rubia and their formation was done through condensation of furomollugin or its derivatives with prenylated hydroquinone derivatives by different ways of condensation ${ }^{5,32,33,45 \& 47}$. The possible biosynthetic pathway of formation of this compound can be suggested by the oxidation with concomitant allylic transposition of prenylated naphthoquinone [a] a known natural product previously isolated from family Rubiaceae which afford the reactive vinyl quinone $[b]$ as a hypothetical biosynthetic intermediate that by acid-catalyzed or photochemical isomerization would yield furomollugin derivatives $[\mathrm{c}]^{5}$. The condensation of two furomollugin derivatives with the removal of water molecule will give compound $\mathbf{1}$ as shown in figure 2. From all the abovementioned data, compound $\mathbf{1}$ was identified as a new naphthohydroquinone dimer with the structure as shown in figure 1 .

Compound 2: colourless needle crystals that gave positive colour with LiebermannBurchard's test suggested its triterpenoidal nature. The molecular formula was deduced to be $\mathrm{C}_{30} \mathrm{H}_{52} \mathrm{O}$ from ${ }^{1} \mathrm{H}$ - and ${ }^{13} \mathrm{C}$ - including DEPT ${ }^{13} \mathrm{C}$-NMR and MS spectra. The ${ }^{13} \mathrm{C}$-NMR spectrum showed the presence of signals for 30 carbon atoms which with the DEPT ${ }^{13} \mathrm{C}-\mathrm{NMR}$ showed the presence of eight methyl, eleven methylene, four methine, one oxymethine and six quaternary carbon atoms confirming the triterpenoidal skeleton. Comparing the ${ }^{1} \mathrm{H}$ - and ${ }^{13} \mathrm{C}-\mathrm{NMR}$ data of the compound with similar compounds $^{48}$, the data can be interpreted as follow: the ${ }^{1} \mathrm{H}-\mathrm{NMR}$ showed the presence of one doublet methyl signal at $\delta_{\mathrm{H}} 0.93(\mathrm{~J}=8 \mathrm{~Hz})$ $\left(\delta_{\mathrm{C}}\right.$ 11.85) which assigned for $\mathrm{C}-23$; seven singlet methyl signals at $\delta_{\mathrm{H}} 1.15\left(\delta_{\mathrm{C}} 32.01\right)$; $0.98\left(\delta_{\mathrm{C}} 16.62\right) ; 0.97\left(2 \mathrm{CH}_{3}\right)\left(\delta_{\mathrm{C}} 18.88\right.$ and $32.31) ; 0.92\left(\delta_{\mathrm{C}} 20.34\right) ; 0.91\left(\delta_{\mathrm{C}} 35.25\right)$ and $0.84\left(\delta_{\mathrm{C}} 18.47\right)$ which assigned for C-28, C-24, C-27, C-30, C-26, C-29 and C-25, in addition to a broad singlet at $\delta_{\mathrm{H}} 3.72\left(\delta_{\mathrm{C}} 72.97\right)$ which assigned for C-3. The chemical shifts were found to be close to friedelane triterpene nucleus having an oxygenated carbon ${ }^{48}$. Comparing these data with the data reported for $3-\beta$-friedelinol confirmed its identity ${ }^{49}$. The assignment of the structure was supported by the EI-MS, which exhibited beside the molecular ion peak at $\mathrm{m} / z 428[\mathrm{M}]^{+}$, other peaks at $\mathrm{m} / z 413$ (29), 275 (36), 248 (19), 231 (30) and 95 (100, base peak). Based on these evidences, the structure of compound 2 was deduced as 3- $\beta$-friedelinol (Fig. 1). Friedelinol type triterpene was previously isolated from the family Rubiaceae (Paederia foetida) ${ }^{50}$ but this is the first report for its isolation from the genus Rubia.

Compound 3: The ${ }^{13} \mathrm{C}-\mathrm{NMR}$ including DEPT spectra showed the presence of ten carbon signals including six quaternary, one methine, two methyls and one methoxy groups. The ${ }^{1} \mathrm{H}-$ NMR spectrum showed the presence of four singlet signals; one in the aromatic region at $\delta_{\mathrm{H}}$ $6.19(1 \mathrm{H})$ and three in the aliphatic region at $\delta_{\mathrm{H}}$ $2.08,2.43$ and $3.90(3 \mathrm{H}$, each), in addition to chelated hydroxyl group at $\delta_{\mathrm{H}} 12.00$. The aromatic proton and six carbons at $\delta_{\mathrm{C}} 105.37$ (C), 163.36 (C), 108.75 (C), 158.37 (C), 110.77 $(\mathrm{CH}), 140.32(\mathrm{C})$ indicated the presence of penta-substituted benzene ring; the two signals at $\delta_{\mathrm{C}} 7.88$ and 24.31 were assigned for the two aromatic methyls and the two signals at $\delta_{C}$ 52.01 and 169.76 were assigned for the carbomethoxy group. The full identification of this compound was deduced by 2D NMR spectroscopy including HSQC and HMBC. The HMBC spectrum (Fig. 1) showed correlations between the proton at $\delta_{\mathrm{H}} 6.19$ with carbons at $\delta_{\mathrm{C}} 105.37,108.75$ and 24.31 ; protons at $\delta_{\mathrm{H}} 2.43$ with carbons at $\delta_{\mathrm{C}} 110.77$ and 105.37 ; protons at $\delta_{\mathrm{H}} 2.08$ with carbons at $\delta_{\mathrm{C}} 163.36$ and 158.37 and finally the methoxy protons at $\delta_{\mathrm{H}} 3.90$ with the carbonyl carbon at $\delta_{\mathrm{C}} 172.82$. Final identification was supported by MS which showed $[\mathrm{M}]^{+}$at $\mathrm{m} / \mathrm{z} 196$ corresponding to the molecular formula $\mathrm{C}_{10} \mathrm{H}_{12} \mathrm{O}_{4}$. Comparing these data with that reported for similar compounds indicated that this compound is atraric acid which isolated from many plants as Pygeum africanum, Newbouldia laevis, Ekebergia pterophylla and Evernia prunastri ${ }^{51-54}$. Although, many phenolic acid derivatives were isolated from the genus Rubia ${ }^{33 \& 55}$, this is the first report about the isolation of atraric acid from the family Rubiaceae. 


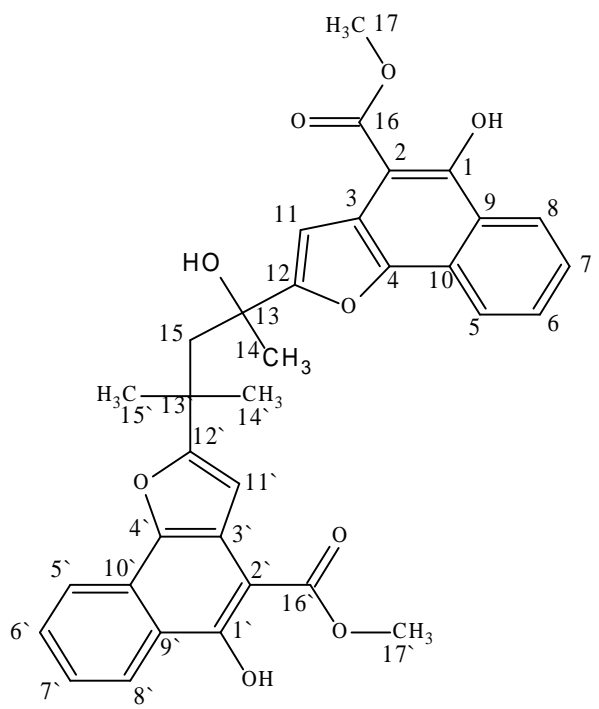

1

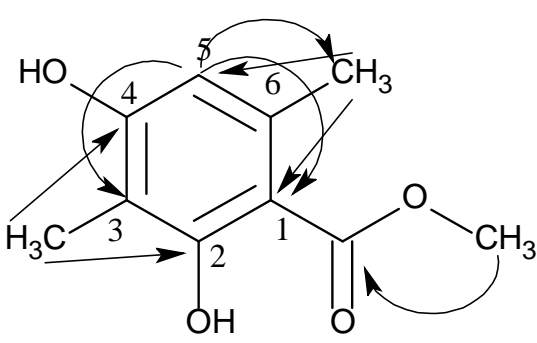

3<smiles>COc1cc(C(=O)O)ccc1O</smiles>

4

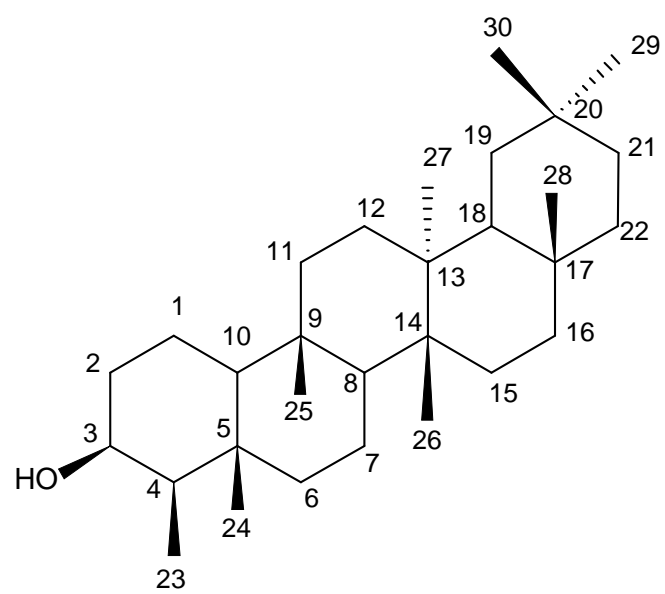

2

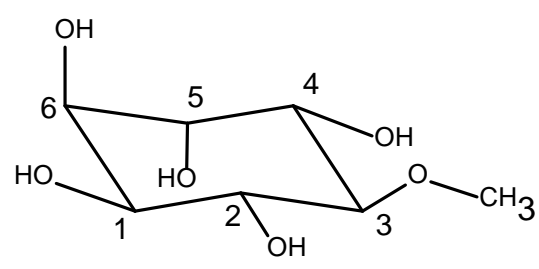

5

Fig. 1: Structures of compounds (1-5) and HMBC of $\mathbf{3}$.<smiles>CC(C)=CCC1=C(C(=O)O)C(=O)c2ccccc2C1=O</smiles>

[a]<smiles>COC(=O)C1=C(C=CC(C)(C)O)C(=O)c2ccccc2C1=O</smiles>

$[\mathrm{b}]$<smiles>COC(=O)c1c(O)c2ccccc2c2oc(C(C)(C)O)cc12</smiles>

$[\mathrm{c}]$

Prenylated naphthoquinone

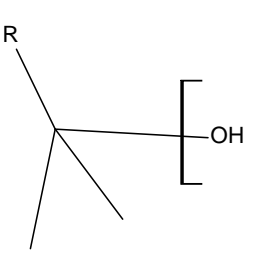<smiles>[R]C(C)(O)CC([2H])(C)C</smiles><smiles>COC(=O)C(C)C1CC(C(C)(C)C)OC1C</smiles><smiles>CCC(C)(C)C1CC2C3CCCCC3C(O)C(C(O)OC)C2C1</smiles>

$\mathrm{R}=$ furomollugin moiety

Fig. 2: The possible biosynthetic pathway of the compound $\mathbf{1}$. 
Compound 4: The ${ }^{1} \mathrm{H}-\mathrm{NMR}$ spectrum of compound 4 showed the presence of three peaks in the aromatic region at $\delta_{\mathrm{H}} 8.04(1 \mathrm{H}, \mathrm{d}$, $J=1.9 \mathrm{~Hz}), 8.13(1 \mathrm{H}, \mathrm{dd}, J=1.9,8.2 \mathrm{~Hz})$ and $7.31(1 \mathrm{H}, \mathrm{d}, J=8.2 \mathrm{~Hz})$ indicated the presence of trisubstituted benzene ring with $\mathrm{ABX}$ system while the singlet signal at $\delta_{\mathrm{H}} 3.94(3 \mathrm{H})$ suggested the presence of methoxy group. This data with the aid of MS at $\mathrm{m} / z \quad 169[\mathrm{M}+1]^{+}$ corresponding to the molecular formula $\mathrm{C}_{8} \mathrm{H}_{8} \mathrm{O}_{4}$ and physical properties (experimental part) in addition to the reported data indicated that compound $\mathbf{4}$ is vanillic acid which was previously reported from Rubia yunnanensis ${ }^{55}$ but this is the first report about its isolation from this species.

Compound 5: The ${ }^{13} \mathrm{C}-\mathrm{NMR}$ data of the compound showed the presence of seven carbon signals for seven carbons including one methoxy at $\delta_{\mathrm{C}} 59.39$ and six oxygenated methine atoms resonating at $\delta_{\mathrm{C}} 70.62,71,13$, 72.06, 72.34, 72.91 and 83.51. The ${ }^{1} \mathrm{H}-\mathrm{NMR}$ data revealed the absence of aromatic and presence of aliphatic groups as follow: $\delta_{\mathrm{H}} 3.27$ $(1 \mathrm{H}, \mathrm{t}, J=9.2 \mathrm{~Hz}), 3.58(1 \mathrm{H}, \mathrm{t}, J=9.2 \mathrm{~Hz}), 3.69$ $(1 \mathrm{H}, \mathrm{dd}, J=2.4,10.0 \mathrm{~Hz}), 3.73(1 \mathrm{H}, \mathrm{dd}, J=2.4$, $10.0 \mathrm{~Hz}), 3.88(2 \mathrm{H}, \mathrm{m})$. The chemical shifts of the oxymethine groups indicated the presence of inositol moiety ${ }^{56}$ substituted with one methoxy group. Comparing the chemical shift with the reported inositol isomers ${ }^{46}$ indicated that the compound is chiro-inositol substituted at C-3 with the methoxy group, thus the compound was identified as D-3-O-methoxychiro-inositol and this is the first report about its isolation from the genus Rubia.

\section{REFERENCES}

1- H. Morita, T. Yamamiya, K. Takeya and H. Itokawa, "New antitumor bicyclic hexapeptides, RA-XI, XII, XIII and XIV from Rubia cordifolia", Chem. Pharm. Bull., 40, 1352-1354 (1992).

2- J. Lee, Y. Hitotsuvanagi and K. Takeya, "Structures of cytotoxic bicyclic hexapeptides, RA-XIX, -XX, -XXI, and XXII, from Rubia cordifolia L", Tetrahedron, 64, 4117-4125 (2008) and references cited in.

3- J. E. Lee, Y. Hitotsuyanagi, H. Fukaya, K. Kondo and K. Takeya, "New cytotoxic bicyclic hexapeptides, RA-XXIII and RAXXIV from Rubia cordifolia L", Chem. Pharm. Bull., 56, 730-733 (2008).

4- J. E. Lee, Y. Hitotsuyanagi, I. H. Kim, T. Hasuda and K. Takeya, "A novel bicyclic hexapeptide, RA-XVIII, from Rubia cordifolia: structure, semi synthesis, and cytotoxicity", Bioorg. Med. Chem. Lett., 18, 808-811 (2008).

5- J. P. Lumb and D. Trauner, "Biomimetic synthesis and structure elucidation of Rubicordifolin, a cytotoxic natural product from Rubia cordifolia", J. Am. Chem. Soc., 127, 2870-2871 (2005).

6- M. Shoemaker, B. Hamilton, S. H. Dairkee, I. Cohen and M. J. Campbell, "In-vitro anticancer activity of twelve Chinese medicinal herbs", Phytother. Res., 19, 649-651 (2005).

7- N. Deshkar, S. Tilloo and V. Pande, "A comperhensive review of Rubia cordifolia L.", Pharmacognosy Reviews, 2, 124-134 (2008) and references cited in.

8- P. R. Patel, B. P. Raval, H. A. Karanth and V. R. Patel, "Potent antitumor activity of Rubia cordifolia", Int. J. Phytomedicine, 2, 44-46 (2010).

9- P. P. Gupta, R. C. Srimal, N. Verma and J. S. Tandon, "Biological activity of Rubia cordifolia and isolation of an active principle", Pharm. Biol., 37, 46-49 (1999).

10- S. Ghosh, M. Das Sarma, A. Patra and B. Hazra, "Anti-inflammatory and anticancer compounds isolated from Ventilago madraspatana Gaertn., Rubia cordifolia Linn. and Lantana camara Linn", J. Pharm. Pharmacol., 62, 1158-1166 (2010).

11- S. Basu, A. Ghosh and B. Hazra, "Evaluation of the antibacterial activity of Ventilago madraspatana Gaertn. Rubia cordifolia Linn. and Lantana camara Linn.: isolation of emodin and physcion as active antibacterial agents", Phytother. Res., 19, 888- 894 (2005).

12- R. Singh, A. Jain, S. Panwar, D. Gupta and S. K. Khare, "Antimicrobial activity of some natural dyes", Dyes and Pigments, 66, 99-102 (2005).

13- S. B. Kasture, V. S. Kasture and C. T. Chopde, "Anti-inflammatory activity of Rubia cordifolia roots", J. Nat. Rem., 1, 111-115 (2001). 
14- P. Jaijesh, K. K. Srinivasan, K. P. Bhagath, G. Sreejith and A. M. Ciraj, "Anti-arthritic property of the plant Rubia cordifolia Lin", Pharmacologyonline, 1, 107-113 (2008).

15- S. Basu and B. Hazra, "Evaluation of nitric oxide scavenging activity, in-vitro and ex-vivo, of selected medicinal plants traditionally used in inflammatory diseases", Phytother. Res., 20, 896-900 (2006).

16- T. C. Shekhar, Y. M. Bahuguna and S. Vijender, "Anti-inflammatory activity of ethanolic stem extracts of Rubia cordifolia Linn. in rats", Int. J. Res. in Ayurveda and Pharmacy, 1, 126-130 (2010).

17- P. Kaur, S. Kaur, S. Kumar and P. Singh, "Rubia cordifolia L. and Glycyrrhiza glabra L. medicinal plants as potential source of COX-2 inhibitors", Am. J. Biomed. Sci., 2, 108-120 (2010).

18- K. Divakar, A. T. Pawar, S. B. Chandrasekhar, S. B. Dighe and G. Divakar, "Protective effect of the hydroalcoholic extract of Rubia cordifolia roots against ethylene glycol induced urolithiasis in rats", Food Chem. Toxicol., 48, 1013-1018 (2010).

19- A. T. Pawar, D. Kalyani, S. B. Chandrasekar and G. Divakar, "Diuretic activity of root extract of Rubia cordifolia Linn.”, Pharmacologyonline, 1, 597-603 (2009).

20- S. J. Rani, R. Nagarauk and P. Anuradha, "Antibacterial properties of extracts of Indian medicinal plants: Syzygium alternifolium, Phyllanthus niruri and Rubia cordifolia", Biomed. Pharmacol. J., 3, 123-128 (2010).

21- K. C. Naidu, R. Lalam and V. Bobbarala, "Antimicrobial agents from Rubia cordifolia and Glycyrrhiza glabra against phytopathogens of Gossypium", Int. J. Pharm.Tech. Res., 1, 1512-1518 (2009).

22- G. M. M. Rao, C. V. Rao, P. Pushpangadan and A. Shirwaikar, "Hepatoprotective effects of rubiadin, a major constituent of Rubia cordifolia Linn.”, J. Ethnopharmacol., 103, 484-490 (2006).

23- R. Singh and S. M. Chauhan, "9,10anthraquinones and other biologically active compounds from the genus Rubia",
Chem. Biodivers., 1, 1241-1264 (2004) and references cited in.

24- A. K. Meena, B. Pal, P. Panda, R. Sannd and M. M. Rao, "A review on Rubia cordifolia: Its phyto-constituents and therapeutic uses", Drug Invention Today, 2, 244-246 (2010) and references cited in.

25- R. A. Patil, S. C. Jagdale and S. B. Kasture, "Antihyperglycemic, antistress and nootropic activity of roots of Rubia cordifolia Linn”, Indian J. Exp. Biol., 44, 987-992 (2006).

26- R. Baskar, L. M. Bhakshu, G. V. Bharathi, S. S. Reddy, R. Karuna, G. K. Reddy and D. Saralakumari, "Antihyperglycemic activity of aqueous root extract of Rubia cordifolia in streptozotocin-induced diabetic rats", Pharm. Biol., 44, 475-479 (2006).

27- M. T. Harde, A. S. khairrar, A. S. Kasture and S. B. kasture, "Evaluation of antipsychotic and anti-diarrhoeal activities of ethanolic extract of roots of Rubia cordifolia Linn.", Oriental Pharmacy and Experimental Medicine, 8, 73-80 (2008).

28- A. K. Rawal, D. K. Nalh and S. K. Biswas, "Plausible mechanism of antioxidant action of Fagonia cretica Linn, Rubia cordifolia and Tinospora cordifolia, during ischematic reperfusion injury in rat hippocampus", Int. J. App. Res. Nat. Prod., 1, 16-25 (2008).

29- Y. B. Tripathi, S. Shukla, M. Sharma and V. K. Shukla, "Antioxidant property of Rubia cordifolia extract and its comparison with vitamin $\mathrm{E}$ and parabenzoquinone", Phytother. Res., 9, 440-443 (1995).

30- A. A. Joharapurkar, S. P. Zambad, M. M. Wanjari and S. N. Umathe, "In-vivo evaluation of antioxidant activity of alcoholic extract of Rubia cordifolia Linn. and its influence on ethanol-induced immunosuppression", Indian J. Pharmacol., 35, 232-236 (2003).

31- Y. Lu, R. Hu, Z. Dai and Y. Pan, "Preparative separation of anti-oxidative constituents from Rubia cordifolia by column-switching counter-current chromatography”, J. Sepa. Sci., 33, 2200-2205 (2010.).

32- H. Itokawa, Z. Z. Ibraheim, Y. F. Qiao and K. Takeya, "Anthraquinones, naphtho- 
hydroquinones and naphthohydroquinone dimers from Rubia cordifolia and their cytotoxic activity", Chem. Pharm. Bull., 41, 1869-1872 (1993).

33- H. A. Hassanean, Z. Z. Ibraheim, K. Takeya and H. Itokawa, "Further quinoidal derivatives from Rubia cordifolia L.", Pharmazie, 55, 317-319 (2000).

34- Z. Z. Ibraheim, "Triterpenes from Rubia cordifolia L.", Bull. Pharm. Sci. Assiut Univ., 25, 155-163 (2002).

35- Z. Z. Ibraheim, "Saponins, naphthohydroquinones and anthraquinone glycosides from Rubia cordifolia L", ibid., 25, 85-94 (2002).

36- Z. Z. Ibraheim and A. S. Ahmed, "Further constituents from Rubia cordifolia L. root", Bull. Fac. Pharm. Cairo Univ., 47, 233-243 (2009).

37- R. Liu, Y. Lu, T. Wu and Y. Pan, "Simultaneous isolation and purification of mollugen and two anthraquinones from Rubia cordifolia by HSCCC", Chromatographia, 68, 95-99 (2008).

38- M. Miyazawa and J. Kawata, "Identification of the key aroma compounds in dried roots of Rubia cordifolia", J. Oleo-Science, 55, 37-39 (2006).

39- N. P. Mishchenko, S. A. Fedoree, V. M. Bryukhano, Ya. F. Zverev, V. V. Lampatov, O. V. Azarova, Yu. N. Shkry and G. K. Chernaded, "Chemical composition and pharmacological activity of anthraquinones from Rubia cordifolia cell culture", Pharm. Chem. J., 41, 605609 (2007).

40- D. Gupta, S. Kumari and M. Gulrajani, "Studies with hydroxyanthraquinones extracted from Indian madder. Part 1: Dyeing of nylon with purpurin", Coloration Technology, 117, 328-332 (2001).

41- Y. Lu, R. Liu, C. Sun and Y. Pan, "An effective high-speed countercurrent chromatographic method for preparative isolation and purification of mollugin directly from the ethanol extract of the Chinese medicinal plant Rubia cordifolia", J. Sepa. Sci., 30, 1313-1317 (2007).
42- W. Ma, Y. Lu, X. Dai, R. Liu, R. Hu and Y. Pan, "Determination of anti-tumor constitute mollugin from traditional Chinese medicine Rubia cordifolia: Comparative study of classical and microwave extraction techniques", Separation Science and Technology, 44, 995-1006 (2009).

43- X. Li, Z. Liu, Y. Chen, L. Wang, Y. Zheng, G. Sun and C. Ruan, "Rubiacordone A: A New Anthraquinone glycoside from the roots of Rubia cordifolia", Molecules, 14, 566-572 (2009).

44- M. S. Akhtar, M. Ali, M. Madhuriya, S. R. Mir and O. Singh, "New anthraquinones from Rubia cordifolia roots", Indian J. Chem., 45, 1945-1950 (2006).

45- Y. Qiao, K. Takeya, H. Itokawa and Y. Iitaka, "Three novel naphthohydroquinone dimers from Rubia oncotricha", Chem. Pharm. Bull., 38, 2896-2898 (1990).

46- E. Breitmaier and W. Voelter, "Crabon-13 NMR spectroscopy", VCH Verlagsgesellschaft, Weinheim, Third, Completely Revised Edition (1987).

47- J. P. Lumb, K. C. Choong, and D. Trauner, "Ortho-quinone methides from paraquinones: Total synthesis of rubioncolin B”, J. Am. Chem. Soc., 130, 9230-9231 (2008).

48- S. B. Mahato and A. P. Kundu, " ${ }^{13}$ C NMR spectra of pentacyclic triterpenoids - A compilation and some salient features. Review article", Phytochemistry, 37, 1517-1575 (1994).

49- G. C. M. Salazar, G. D. F. Silva, L. P. Duarte, S. A. Vieira Filho and I. S. Lula, "Two epimeric friedelane triterpenes isolated from Maytenus truncata Reiss: ${ }^{1} \mathrm{H}$ and ${ }^{13} \mathrm{C}$ chemical shift assignments", Magn. Reson. Chem., 38, 977-980 (2000).

50- C. P. Khare, "Indian Herbal Remedies: Rational Western Therapy, Ayurvedic, and Other Traditional Usage, Botany", Springer-Verlag Berlin Heidelberg New York, 2004, p. 347.

51- M. Papaioannou, S. Schleich, I. Prade, S. Degen, D. Roell, U. Schubert, T. Tanner, F. Claessens, R. Matusch and A. Baniahmad, "The natural compound atraric acid is an antagonist of the human androgen receptor inhibiting cellular 
invasiveness and prostate cancer cell growth", J. Cell. Mol. Med., 13, 22102223 (2009).

52- R. Gormann, M. Kaloga, X-C. Li, D. Ferreira, D. Bergenthal and H. Kolodziej, "Furanonaphthoquinones, atraric acid and a benzofuran from the stem barks of Newbouldia laevis", Phytochemistry, 64, 583-587 (2003).

53- D. A. Mulholland, S. E. Iour1ne, D. A. H. Taylor and F. M. Dean, "Coumarins from Ekebergia pterophylla", ibid., 47, 16411644 (1998).

54- A. M. Ahad, Y. Goto, F. Kiuchi, Y. Tsuda, K. Kondo and T. Sato, "Nematocidal principles in oakmoss absolute and nematocidal activity of 2,4dihydroxybenzoates", Chem. Pharm. Bull., 39, 1043-1046 (1991).
55- J. Tao, T. Morikawa, S. Ando, H. Matsuda and M. Yoshikawa, "Bioactive Constituents from Chinese Natural Medicines. XI. Inhibitors on NO Production and Degranulation in RBL2H3 from Rubia yunnanensis: Structures of Rubianosides II, III and IV, Rubianol-g, and Rubianthraquinone", ibid., 51, 654662 (2003).

56- C. Sridhar, A. V. Krishnaraju and G. V. Subbaraju, "Antiinflammatory constituents of Teramnus labialis", Indian J. Pharm. Sci., 68, 111-114 (2006). 